心胸郭比の変化
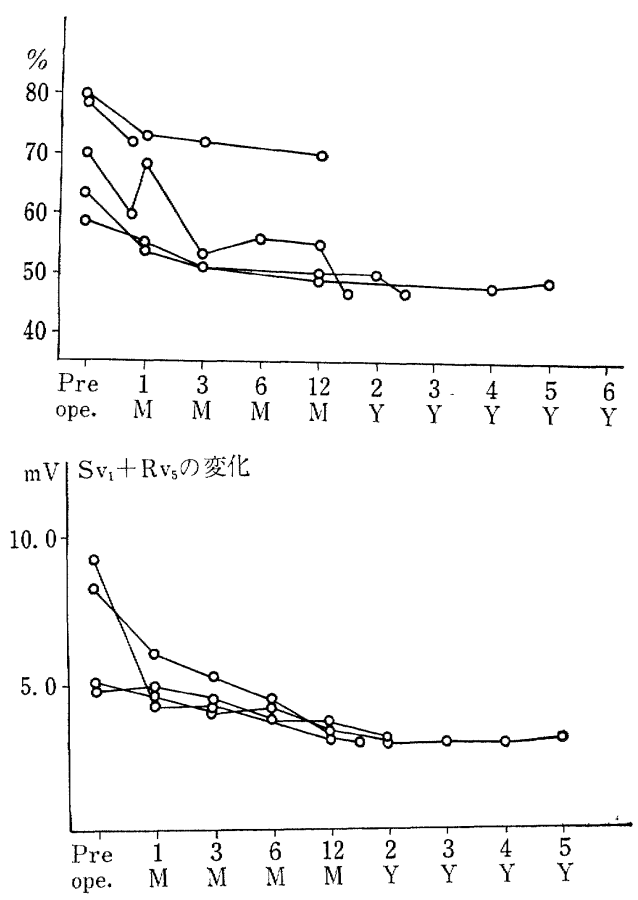

の後の症例ではドレーン抜去前に抗凝固療法を開始し， 出血の無いことを確認後ドレーンを拔去するようにして いる. composite graft はすべて Björk-Shiley 弁を用 いて作成したが，抗凝固療法を強力に行なわなくてわよ いこと，graft 内で中心流が得られることなどから生体 弁を用いた composite graft の使用子今後検討してよい 方法と考学られる.

表 1 に示すごとく, 大動脈弃閉鎖不全を伴なう上行大 動脈瘤は病態の進行が早く, 重篤であるが, 術後の症状, 胸部 $\mathrm{X}$ 線写真や心電図所見の改善は, 同期間にわれわれ の経験したリウマチ性変化による大動脈弁置換術例より も早く, 早期に手術を行うべきであると痛感した。

以上.われわれの経験した大動脈瘤に対する composite graftを用いた手術例を若下の考察を加えて報告した.

文 献 1) Bentall H, DeBono A: Thorax 23: 388, 1968. 2) Galloti R, Ross DN: Ann Thorac Surg 29: 428, 1980. 3) Kouchoukos NT et al.: Ann Surg. 192: 403, 1980.4 4) Mayer, JE Jr.,: J. Thorac Cardiovasc Surg 76: 816, 1978. 5) Cabrol C.: J. Thorac Cardiovasc Surg 81: 309, 1981.

図 1

\title{
S-2-4 真性胸部大動脈瘤外科治療上の問題点
}

\begin{tabular}{lllllll}
\multicolumn{8}{c}{} & 小含記念病院 & \multicolumn{1}{c}{ 心藏血管外科 } & & \\
西村 & 和修 & 伴 敏彦 & 松田 & 光彦 & 望月 & 高明 \\
坂田 & 隆造 & 曽根田純一 & 平田 & 和男 & 花田 & 正治
\end{tabular}

はじめに

真性胸部大動脈瘤のうち, とく纪 annuloaortic ectasia (AAE) 飞対する Bentall 術式の成績, 弓部大動脈癐に 対する補助手段法，さらに手術手技の困難な石兏化著明 例に対する手術術式について検討した.

\section{手術方法と成績}

過去 9 年間に真性胸部大動脈瘤 19 例の手術を施行し た. 部位別では上行部 12 例, 弓部 2 例, 下行部 4 例,

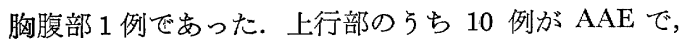
2 例が心外性バルサルバ洞動脈瘤であった（表 1 ）.
AAE に対し Bentall 手術を9例に施行し, AVR + wrapping を1例に施行した(表 2). 病因はマルファン症 候群または中膜変性によるものが 3 例, 梅毒性 2 例, 大 動脈炎症候群 1 例, 不明 4 例であった. 心筋保護法とし 七初期の 6 例飞選択的冠灌流法, 後期の 4 例飞 Young および GIK 液による cardioplegia 法を用いたが成績 飞差は認めなかった，病院死は 2 例で遠隔死はなかった。 死亡例のうち症例(6)術前より高度の心不全叔よび腎不 全があり，緊急手術を行ったが腎不全が改善せず死亡し た立・症例10は上行大動脈遠位部の石灰化が強かったため に吻合部よりの出血のコントロールに難渋し, 大量輸血 を必要とした症例である，何とが正血できたが術翌日， 
表 1 真性胸部大動脈瘤

\begin{tabular}{|c|c|c|c|c|}
\hline$\therefore$ & 䢶 & 位 & 症例数 & 病院死 \\
\hline \multicolumn{5}{|c|}{ 行 } \\
\hline \multicolumn{3}{|c|}{ A A E } & 10 & 2 \\
\hline \multicolumn{3}{|c|}{ 心外性バルサルバ洞動脈瘤 } & 2 & 0 \\
\hline 弓 & & 部 & 2 & 2 \\
\hline 下 & 行 & 部 & 4 & 0 \\
\hline \multirow[t]{2}{*}{ 胸 } & 腹 & 部 & 1 & 1 \\
\hline & 計 & & 19 & 5 \\
\hline
\end{tabular}

AAE : Annulo-aortic Ectasia

遠隔死：なし

㔖然血圧低下をきたして死亡した．剖検はできなかった が，おそらく人工血管と被覆大動脈壁との間に血腫を生 じて，急性大動脈弁上狭窄を来たしたものと推測した。 合併症は遠隔期も含めて，他炕々の発生を認めなかった。 心外性バルサルバ洞動脈瘤が 2 例めり，結果は良好で あった. 1 例は梅毒性で石灰化が強く，大動脈一左室圧 較差 $80 \mathrm{mmHg}$ の $\mathrm{AS}$ ，お。び両冠動脈口狭窄を伴って いた. 人工弁付の composite graft で上行大動脈を置換 し，さらに LAD, RCA へ静脈グラフトを吻合し，両 冠動脈基部と結紮して良好な結果を得た。

弓部大動脈瘤の 2 例飞対し, Hou Yu-Lin 法により手 術を施行した． 1 例は脳障害で死亡した。もう1例も軽 度の脳障害があったが軽快し，比較的良好な経過をたぞ っていたが，非ケトン性高浸透圧性昏睡にて死亡した。 弓部大動脈瘤に対してわれわれが用いた補助手段を図 1 に示したまず下行大動脈と人工血管を端側吻合し（図 1-a)，次に人工血管と各分枝を端側吻合する. 腕頭動 脈への吻合は人工血管を interposition する (図 1-b). 次に全身ヘパリン化し，人工心肺下に上行大動脈と人工 血管を端々吻合する（図1-c)，最後に下行大動脈の人工 血管吻合部より中枢側で動脈を閉鎖して動脈溜を切開し， 瘤切除を行 5 . この方法の特徴は人工心肺時間が短くて すみ，しかる簡便に吻合ができる点にある，しかし，残 念ながらわれわれの症例では 2 例共脳障害が発生してし まった。

下行部動脈溜は人工血管置換術 2 例, パッチ閉鎖術 1 例, 試験開胸術 1 例で死亡例はなかった，人工血管置換 術を施行した症例は 2 例とも紡鏵型で一時バイパス法を 用い忍，パッチ閉鎖術を施行した症例は梅毒性の囊状型 動脈瘤で，弓部の後方に大きく拡大していた．開口部の 死灭化が著明で，な挆かつ動脈溜の剩離が困難であった ため, 開口部のパッチ閉鎖にとどめた．結果は良好で動 脈㾇に縮小した。

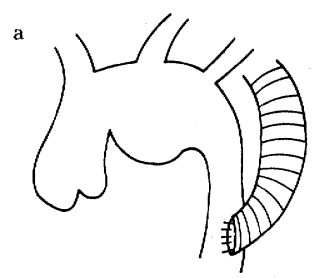

下行部と人工血管吻合

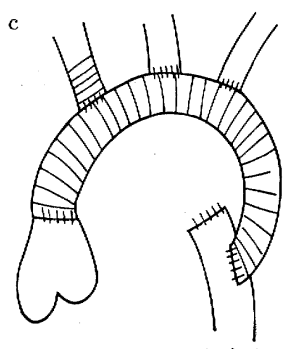

人工心肺下:上行部と 人工血管吻合

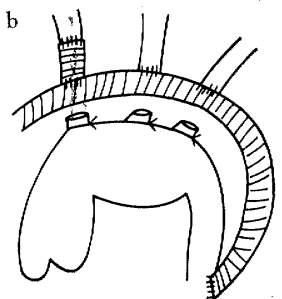

各分枝を人工血管と吻合 腕頭動脈は人工血管で interposition
図 1 弓部大動脈瘁術式

胸腹部大動脈瘤の 1 例は紡錘型で一時バイパス下に手 術を施行した. 内膜の石灰化が強く, とくに Th $8 \sim 11$ の肋間動脈付近で著明であった．Th 8 付近までの内膜 は切除し，これ以下は内膜及び肋間動脈を温存して, spinal- circulation の維持に留意するつるりであった. しかし，あまりに動脈籕壁が硬くて縫縮が不可能であっ たため，内膜の切除を下方に伸ばしたところ Th 10 ま での肋間動脈を損傷してしまった．このため術後対麻瘁 を起こし敗血症で死亡した。

\section{考察}

AAE に対し Bentall 手術を9例に施行したが，1例 は術前よりあった腎不全で死亡したものであり，これを 除外すると 8 例中 1 例の死亡となり，良好な成績と言兄 る. Bentall 手術の合併症としては一般に冠動脈吻合部 縫合不全，冠動脈閉塞，遠位部人工血管縫合不全, perivalvular leakage，血腫による人工血管の狭窄なぞがあ ザられる1,2)．われわれは血腫による急性の人工血管狭 窄を 1 例記認めただけで他に合併症はみなかった。しば しば問題とされる冠動脈吻合法は，一層の連続縫合のみ で行っているが現在まで縫合不全や，冠動脈閉塞なぞの 合併症は発生していない，一層縫合でもていねいに縫光 ば充分ではないかと考えている.

弓部大動脈瘤に対する補助手段として，われわれは Hou Yu-Lin 法3)を用いた。 2 例共脳障害が発生した が，この原因はへパリン化する前の段階で生じた血栓に 
表 2 A $\quad$ A $\quad$ E

\begin{tabular}{|c|c|c|c|c|c|c|c|c|c|c|c|}
\hline 症 & 例 & 性 & 年 令 & 病 & 因 & 式 & 心筋保護法 & 合 & 併 & 症 & 転 帰 \\
\hline 1 & & $\mathrm{~F}$ & 26 & Marfan & 疑 & Bentall & 選択的冠灌流法 & & $(-)$ & & 生 \\
\hline 2 & & $\mathrm{~F}$ & 28 & 不 & 明 & Bentall & "l & 不 & 整 & 脈 & 生 \\
\hline 3 & & $\mathrm{~F}$ & 25 & 不 & 明 & Bentall & "l & & $(-)$ & & 生 \\
\hline 4 & & $\mathrm{~F}$ & 31 & 中膜変 & 性 & Bentall & " & & $(-)$ & & 生 \\
\hline 5 & & M & 33 & 不 & 明 & AVR + Wrapping & " & & $(-)$ & & 生 \\
\hline 6 & & M & 29 & 不 & 明 & Bentall & "l & 腎不 & 全 (術前よ & b) & 死 \\
\hline 7 & & M & 29 & 中膜変 & 性 & Bentall & Young 液+GIK & & $(-)$ & & 生 \\
\hline 8 & & $\mathrm{~F}$ & 34 & 大動脈炎症 & 昰候群 & Bentall & "l & & $(-)$ & & 生 \\
\hline 9 & & M & 56 & 梅 毒 & 性 & Bentall & " & & $(-)$ & & 生 \\
\hline 10 & & $\mathrm{~F}$ & 68 & 梅 毒 & 性 & Bentall & "1 & 大 & 量 出 & 血 & 死 \\
\hline
\end{tabular}

よる脸塞性症であると考えている，したがって，今後は 全身ヘパリン化をもっと早い段階で行い，場合によって は人工血管の preclotting をせずにフィブリン糊の塗布 で代用するなどの対策をとって，血检防止を図るつもり である.このようにすれば本法はな扮有用な方法と判断 している.

動脈瘤に石圧化が著明な場合は，しばしば手術手技を 困難にし，成績も不良となることが多い，われわれの症 例では, 症例(10) $\mathrm{AAE}$, 症例(11)梅毒性心外性バルサル バ洞動脈瘤, 下行部囊状型動脈瘤, 胸腹部大動脈瘤の各 例がこれに相当した，4例中 3 例が梅毒性で，1例は動 脈硬化性であった，症例(11) Bentall 型の手術と A-C バイパスを合せて行い，下行大動脈瘤症例はパッチ閉鎖 のみであるが，いずれも良好な結果を得た，一方，症例 (10では遠位吻合部の石灰化に対し， felt 付きのマットレ ス縫合で補強を試みたがそれでも動脈梳開し，止血困 難であった。 また，胸腹部大動脈瘤の症例も石死化のた めに内膜が剥離してしまって肋間動脈を損傷したもので
あり，今後このような症例における何らかの対策が必要 である。

\section{結語}

1) AAE 10 例中 9 例に Bentall 手術を施行し，2例が 病院死したが遠隔死はなく，手術成績は良好であった。

2） 弓部大動脈瘤 2 例に対し Hau Yu-Lin 法による手 術を施行した. 結果は不良であったが, 今後改良を加 えれば，簡便で安全な補助手段となり得る.

3）石死化著明な動脈瘤では，個々の症例に対し種々 の術式を施行したが, 不良な結果のものもあり, 今後 の検討を要する.

文 献 1) Crosby IK, et al.: Surgery of proximal aorta in Marfan's syndrome. J Thoracic Cardiovasc Surg 66: 75, 1973. 2) 土田弘毅活小: Bentall 手術術後, 上行大動脈瘤を来 乙た1例, 日本胸外会誌 29: 1225，1981. 3) Hou Yu-Lin, et al.: Surgical treatment of aneurysm of thoracic aorta. Chn. Med. J. 83: 740, 1964.

\section{S-2-5 真性胸部大動脈瘤手術症例の検討}

\begin{tabular}{|c|c|c|c|c|c|c|c|}
\hline & & & 腹山大学 & 第 2 外 & & & \\
\hline 内田 & 發三 & 寺本 & 滋 & 妹尾 & 嘉昌 & 名和 & 清人 \\
\hline 11 上 & 俊爾 & 村上 & 泰治 & 清水 & 康広 & 水取 & \\
\hline 中 & 直俊 & 大森 & 義一 & 白川 & 和豊 & 今吉 & \\
\hline
\end{tabular}

はじめに

胸部大動脈の動脈瘤は真性瘤, 解離性瘤が多く, わが
国でも前者の手術成績はようやく安定してきた感がある が，いまだ必ずしも満足すべきものとはいい難い.今回 はわれわれが経験した真性胸部大動脈瘤をとりあげ，そ 